\title{
Response of Pole Type French Bean (Phaseolus vulgaris L.) Genotypes to Sowing Dates in the Mid Hills of Western Nepal
}

\author{
Y.R. Pandey ${ }^{1}$, D.M. Gautam ${ }^{2}$, R.B. Thapa ${ }^{2}$, M.D. Sharma ${ }^{2}$ and K.P. Paudyal ${ }^{3}$ \\ ${ }^{1}$ Regional Agricultural Research Station \\ Lumle, Kaski \\ ${ }^{2}$ Institute of Agriculture and Animal Science \\ Rampur, Chitwan \\ ${ }^{3}$ Horticulture Research Division \\ Khumaltar, Lalitpur \\ e-mail: yrajpandey@yahoo.com
}

\begin{abstract}
Three pole-type French bean (Phaseolus vulgaris L.) genotypes (Four season, Trishuli \& Makwanpur) were sown in different three dates, i.e., August 16, 31 and September 15 during autumn seasons of 2010 and 2011 at the Agriculture Research Station, Malepatan, Pokhara (848 msl) to assess the fresh pod yield and yield attributes of the genotypes in different dates of sowing. The experiment was conducted in randomized complete block design with three replications. The temperature ranged from $14^{\circ}$ to $32^{\circ} \mathrm{C}$ during the growth period. The results showed significant variations in fresh pod yield and yield attributes. Flowering was earlier in Makwanpur genotype. About 50\% plants flowered within 39 days in Makwanpur while it took more than 48 days for Trishuli. Tallest plants were produced by Makwanpur $(271.7 \mathrm{~cm})$ and shortest by Trishuli $(256.2 \mathrm{~cm})$. The pod length was highest $(18.34 \mathrm{~cm})$ in Four season and lowest in Makwanpur (15.07 cm). Pod width was highest in Trishuli (9.04 mm) and lowest in Makwanpur (7.10 $\mathrm{mm})$. Highest fresh pod yield was produced by Four season (25.08 t/ha) followed by Makwanpur (23.11t/ha) and the lowest by Trishuli (19.97 t/ha). Sowing date also showed significant effect on yield and yield attributes. Earliest sowing (16 August) showed better results in early flowering (42.63 days), tallest plants $(280.4 \mathrm{~cm})$, longest pods $(18.51 \mathrm{~cm})$, widest pods $(9.21 \mathrm{~mm})$ and the highest fresh pod yield (31.13 t/ha) than 31 August and 15 September sown conditions. Fresh pod yield was highest in 16 August sown (31.13 t/ha) followed by 31 August (21.74 t/ha) and lowest in 15 September (15.29 t/ha). Four season sown on 16 August produced the highest fresh pod yield with an average of $35.35 \mathrm{t} / \mathrm{ha}$. The result revealed that Four season is the best genotype and mid August is the appropriate sowing time for higher fresh pod yield of French bean in the mid hills of western Nepal.
\end{abstract}

Key words: fresh pod yield, french bean, pole type, genotypes, sowing dates

\section{Introduction}

French bean (Phaseolus vulgaris L.), a native crop of central and South America (Swaider et al. 1992), is one of the oldest cultivated plants. Due to varying climatic adaptability, it can be cultivated from tropical to temperate regions. Bean is one of the important legumes worldwide for human consumption (Singh 1999) and sometime called as "meat of the poor" because of cheap source of protein for poor people. Bean is an important vegetable of Nepal and is cultivated in a wide range of agro-climatic conditions from $300 \mathrm{~m}$ to 2,500 $\mathrm{m}$ asl in different seasons (Neupane et al. 2008). In Nepal, green bean pods are used for fresh vegetable and the dried seeds for pulse purpose while the foliage is used as fodder for animal. Bean cultivation is also beneficial for animals and restoring soil fertility.

French bean is a tender, warm season vegetable that cannot tolerate frost. Its seeds do not germinate below $15^{\circ} \mathrm{C}$ and plants drop blossoms in hot or rainy weather. A mean air temperature of $20^{\circ}-25^{\circ} \mathrm{C}$ is optimum for its growth and better productivity. Extreme high temperatures interfere pod filling, while low temperatures are unfavorable for vegetative growth (ICAR 2003). In a favorable situation the crop can be grown throughout the year. Sowing time has profound 
effect on the productivity of this crop. The optimum sowing time of this bean varies with the type of varieties, growing season, location, etc. In Terai and Inner Terai, it can be profitably grown as a winter crop. In the hills, it is predominantly grown as a rainy season crop. Under irrigated conditions, vegetable types are grown from spring to autumn depending on elevation. Strong interaction effect of genotypes and sowing time on pod and seed yield has been reported by Ali (1989) and Begum et al. (2003). Since most vegetable crops are highly perishable and the market price fluctuation of fresh vegetables is very high. The price difference within a week is very high in Nepalese market. More profit to the farmers determines not only by producing more quantity of vegetables but also by fetching the high market price is more beneficial. Providing such information to the farmers, they could be benefited more by supplying fresh pods in the right time.

A study was conducted at Malepatan, Kaski during the year 2010 to evaluate 19 exotic and indigenous French bean genotypes in spring, summer, rainy and autumn seasons. Among tested genotypes Trishuli, Four season and Makwanpur showed best performance in autumn season (Pandey et al. 2011). This study was therefore undertaken to evaluate aforesaid 3 genotypes of beans, so that recommendations could be made for commercial cultivation of this crop in this area as well as others having similar climatic situation.

\section{Methodology}

The experiment was conducted at the Agriculture Research Station (Horticulture), Malepatan, Pokhara. The station is situated at a latitude of $28^{\circ} 13^{\prime} 6.18^{\prime \prime} \mathrm{N}$ and a longitude of $83^{\circ} 58^{\prime} 27.72 " \mathrm{E}$ at an elevation of $848 \mathrm{~m}$ asl and is characterized by a sub-tropical climate. The experiment was conducted in two consecutive years 2010 and 2011 in two factors factorial randomized complete block design and each treatment combination was replicated three times. The temperature during the growing period ranged from $14^{\circ}$ to $32^{\circ} \mathrm{C}$. Based on previous study three high yielding genotypes; Trishuli, Four season and Makwanpur were used as factor A and dates of sowing: 16 August, 31 August and 15 September was factor B.

Spacing was maintained at $75 \times 45 \mathrm{~cm}$ and experimental plot size was $3.0 \times 1.8 \mathrm{~m}$. Manures and fertilizers were applied as compost (20 t/ha) and 40:60:50 kg NPK/ha, respectively from chemical fertilizers. Scoring of agromorphological characters was done following descriptors for Phaseolus vulgaris (IBPGR 1982). The data were analyzed using Genstat software (version 12.1 VSN International, Hemel Hempstead, UK). Days to flowering was recorded when $50 \%$ of plants had set flowers. Plant height was measured in five randomly selected plants at the green pod maturity stage from the cotyledon scar to the highest tip of the plant. Pod length and width were measured on the largest, fully expanded, immature, green pod and measurements were averaged from 10 randomly selected plants (followed descriptors). Fresh pods were harvested five times (harvestings) for the first date of sowing, four harvestings for the second and three harvestings for the third date of sowing at 10 days interval when they were fully expanded, immature and green stage.

\section{Results and Discussion Days to flowering}

Days to $50 \%$ flowering of a particular variety indicated the earliness, medium or late to mature. The flowering days in different genotypes and sowing dates differed significantly (Table 1). The interaction of genotypes and sowing dates was non significant. The earliest flowering genotype was Makwanpur which flowered within 38.57 days after sowing followed by Four season at 45.14 days and the latest was Trishuli with an average of 48.36 days after sowing. Makwanpur flowered in 37.17, 38.47 and 40.07 days sown on 16, 31 August and 15 September respectively. Early flowering was observed in early sowing. In most of the vegetable crops, early flowering and maturing genotypes were considered preferable. The influence of genotypes, day length and temperature on flower initiation and fruiting of bean has also been reported by other researchers, White and Laing (1989), Neupane et al. (2008), Adams et al.(1985) and Wallace et al. (1991). Their studies showed that the days to flowering and the length of flowering period in beans varied from 40 to 84 days depending on the genotype and environmental conditions which is similar to the results obtained in this study.

\section{Plant height}

The plant height differed significantly among the genotypes and also affected by sowing dates (Table 2 ). The interaction of genotypes and the sowing dates was non significant. The tallest and the shortest plants were in Makwanpur and Trishuli with an average of $271.7 \mathrm{~cm}$ and $256.2 \mathrm{~cm}$, respectively. Similarly, the tallest 
and the shortest plants were in earliest sowing (16 August) and latest sowing (15 September) with an average of $280.4 \mathrm{~cm}$ and $245.6 \mathrm{~cm}$, respectively. The result showed that the plant height was reduced with late sowing in all the genotypes. Neupane et al. (2008) also reported that the plant height in beans was influenced by the genotypes. They recorded that the plant height ranged from 28 to $144 \mathrm{~cm}$ in different bean genotypes that were planted at the same date. Similar results were also reported by other researchers. Alghamdi (2007) reported that faba bean genotypes significantly differed in flowering date and plant height. Al-Soqeer (2010) reported that the plant height in Jojoba clones was affected by the genotype and the growing season ranged from 30.5 to $52.8 \mathrm{~cm}$. French bean sown late i.e., 15 September produced the shorter plants due to sudden temperature reduction during its vegetative growth period.

Table 1. Effect of sowing dates on 50\% flowering of different pole bean genotypes at Malepatan, Kaski, 2010 2011

\begin{tabular}{|c|c|c|c|c|c|}
\hline \multirow[t]{2}{*}{ Genotypes } & \multicolumn{3}{|c|}{ Date of sowing } & \multirow{2}{*}{$\begin{array}{l}\text { Means of } \\
\text { genotypes }\end{array}$} & \multirow{2}{*}{$\begin{array}{l}\text { F value of } \\
\text { genotypes }\end{array}$} \\
\hline & 16 August & 31 August & 15 September & & \\
\hline $\begin{array}{l}\text { Trishuli } \\
\text { Four season } \\
\text { Makwanpur } \\
\text { Means of sowing dates } \\
\text { F - value of sowing date } \\
\text { LSD } \\
\text { LSD }_{0.05} \text { (int.) } \\
\text { CV (\%) }\end{array}$ & $\begin{array}{c}46.97 \\
43.77 \\
37.17 \\
42.63^{\mathrm{C}}\end{array}$ & $\begin{array}{c}48.27 \\
45.13 \\
38.47 \\
43.96^{b}\end{array}$ & $\begin{array}{c}49.83 \\
46.53 \\
40.07 \\
45.48^{\mathrm{a}}\end{array}$ & $\begin{array}{c}48.36^{\mathrm{a} 1} \\
45.14^{\mathrm{b}} \\
38.57^{\mathrm{c}} \\
44.02 \\
23.54^{* *} \\
0.88 \\
\text { ns } \\
2.0\end{array}$ & $289.32 * *$ \\
\hline
\end{tabular}

${ }^{1}$ Mean values in the same column followed by a common letter are not significantly different at the $P<0.05$ level by Duncan's new multiple range test.

** = Highly significant at $P<0.01$ and ns = non significant

Table 2. Effect of sowing dates on plant height (cm) of different pole bean genotypes at Malepatan, Kaski, 2010 2011

\begin{tabular}{|c|c|c|c|c|c|}
\hline Genotypes & 16 August & $\begin{array}{l}\text { Date of sowing } \\
31 \text { August }\end{array}$ & 15 September & $\begin{array}{l}\text { Means of } \\
\text { genotypes }\end{array}$ & $\begin{array}{l}\text { F value of } \\
\text { genotypes }\end{array}$ \\
\hline $\begin{array}{l}\text { Trishuli } \\
\text { Four season } \\
\text { Makwanpur } \\
\text { Means of sowing dates } \\
\text { F - value of sowing date } \\
\text { LSD } \\
\text { LSD }_{0.05} \text { (int.) } \\
\text { CV (\%) }\end{array}$ & $\begin{array}{c}270.10 \\
281.60 \\
289.50 \\
280.40^{\mathrm{a}}\end{array}$ & $\begin{array}{c}258.50 \\
270.30 \\
275.70 \\
268.20^{b}\end{array}$ & $\begin{array}{l}239.90 \\
247.10 \\
249.90 \\
245.60^{\mathrm{C}}\end{array}$ & $\begin{array}{c}256.20^{\mathrm{b} 1} \\
266.30^{\mathrm{a}} \\
271.70^{\mathrm{a}} \\
264.70 \\
60.16^{* *} \\
6.82 \\
\text { ns } \\
2.6\end{array}$ & $11.96 * *$ \\
\hline
\end{tabular}

${ }^{1}$ Mean values in the same column followed by a common letter are not significantly different at the $P<0.05$ level by

Duncan's new multiple range test.

$* *=$ Highly significant at $P<0.01$ and ns = non significant

\section{Pod length}

The pod length among the genotypes and sowing dates were significantly different while the interaction effect was non significant (Table 3). The combined analysis over the years showed that the longest pods were produced by Four season with an average of $18.34 \mathrm{~cm}$ and the shortest by Makwanpur $(15.07 \mathrm{~cm})$.
Similarly, the longest pods were produced when the crop was sown on 16 August $(18.51 \mathrm{~cm})$ and the shortest $(15.22 \mathrm{~cm})$ by $15^{\text {th }}$ September sown ones. The length was found higher in early sowing as compared to late sowing. Neupane et al. (2008) reported variations in pod length in different genotypes. They found that all the genotypes planted on the same date 
produced varying pod lengths ranging from 6.7 to 17.4 $\mathrm{cm}$. Similar results were also reported by other researchers. Islam et al. (2010) reported that the genotypes of hyacinth bean showed considerable variation in pod length varying from 3.96 to $18.20 \mathrm{~cm}$.
Pengelly and Maass (2001) also reported that the pod length in lablab bean ranged from 2.5 to $14 \mathrm{~cm}$ among 249 genotypes. During the growth period of fresh pods, the temperature was suddenly low and affected the growth of green pods of all genotypes.

Table 3. Effect of sowing dates on pod length (cm) of different pole bean genotypes at Malepatan, Kaski, 2010 2011

\begin{tabular}{|c|c|c|c|c|c|}
\hline \multirow[t]{2}{*}{ Genotypes } & \multirow[b]{2}{*}{16 August } & \multicolumn{2}{|c|}{ Date of sowing } & \multirow{2}{*}{$\begin{array}{l}\text { Means of } \\
\text { genotypes }\end{array}$} & \multirow{2}{*}{$\begin{array}{l}\text { F value of } \\
\text { genotypes }\end{array}$} \\
\hline & & 31 August & 15 September & & \\
\hline $\begin{array}{l}\text { Trishuli } \\
\text { Four season } \\
\text { Makwanpur } \\
\text { Means of sowing dates } \\
\text { F - value of sowing date } \\
\text { LSD } \\
\text { LSD }_{0.05} \text { (int.) } \\
\text { CV (\%) }\end{array}$ & $\begin{array}{c}19.67 \\
19.77 \\
16.10 \\
18.51^{\mathrm{a}}\end{array}$ & $\begin{array}{c}18.70 \\
18.87 \\
15.43 \\
17.67^{\mathrm{b}}\end{array}$ & $\begin{array}{c}15.60 \\
16.40 \\
13.67 \\
15.22^{\mathrm{C}}\end{array}$ & $\begin{array}{c}17.99^{\mathrm{a} 1} \\
18.34^{\mathrm{a}} \\
15.07^{\mathrm{b}} \\
17.13 \\
47.17^{* *} \\
0.75 \\
\text { ns } \\
4.4\end{array}$ & $52.30 * *$ \\
\hline
\end{tabular}

${ }^{1}$ Mean values in the same column followed by a common letter are not significantly different at the $P<0.05$ level by

Duncan's new multiple range test.

** = Highly significant at $P<0.01$ and ns = non significant

\section{Pod width}

The genotypes and sowing dates had significant effect on pod width but the interaction of genotypes and the sowing dates was non significant (Table 4). The combined analysis over the years showed that the widest pods were produced by Trishuli with an average of $9.04 \mathrm{~mm}$ and the narrowest by Makwanpur with an average of $7.10 \mathrm{~mm}$. Similarly, the widest pods were produced when the crop was sown on 16 August with an average of $9.21 \mathrm{~mm}$ and the narrowest (6.74 $\mathrm{mm}$ ) by $15^{\text {th }}$ September sown ones. Neupane et al. (2008) also reported variations in pod length in different genotypes. They recorded pod widths ranging from 10 to $30 \mathrm{~mm}$ in different genotypes planted at the same date. Islam et al. (2010) also reported that the genotypes of hyacinth bean showed considerable variation in pod width that ranged from 1.5 to $4.46 \mathrm{~cm}$. Pengelly and Maass (2001) reported that the pod width in lablab bean showed high variation among 249 genotypes. During the growth period of fresh pods, the temperature was suddenly low and affected the growth of green pods of all genotypes. The width was found higher in early sowing as compared to late sowing. The reason might be the effect of low temperature which retarded the plant and pod growth.

Table 4. Effect of sowing dates on pod width (mm) of different pole bean genotypes at Malepatan, Kaski, 2010-2011

\begin{tabular}{|c|c|c|c|c|c|}
\hline \multirow[t]{2}{*}{ Ge notypes } & \multicolumn{3}{|c|}{ Date of sowing } & \multirow{2}{*}{$\begin{array}{l}\text { Mears of } \\
\text { genotypes }\end{array}$} & \multirow{2}{*}{$\begin{array}{l}\text { F value of } \\
\text { ge notypes }\end{array}$} \\
\hline & 16 August & 31 August & 15 September & & \\
\hline $\begin{array}{l}\text { Trishuli } \\
\text { Four season } \\
\text { Makwanpur } \\
\text { Mears of so wing dates } \\
\text { F - value of sowing date } \\
\text { LSD } \\
\text { LSD }_{0.09} \text { (int.) } \\
\text { CV }(\%)\end{array}$ & $\begin{array}{c}10.37 \\
9.50 \\
7.77 \\
9.21^{\star}\end{array}$ & $\begin{array}{l}9.50 \\
9.10 \\
7.27 \\
8.62^{\circ}\end{array}$ & $\begin{array}{l}7.25 \\
6.70 \\
6.27 \\
6.74^{6}\end{array}$ & $\begin{array}{c}9.04^{\text {al }} \\
8.43^{\mathrm{b}} \\
7.10^{6} \\
8.19 \\
107.27^{* * *} \\
0.37 \\
\text { ns } \\
4.6\end{array}$ & $63.29 * *$ \\
\hline
\end{tabular}

${ }^{1}$ Mean values in the same column followed by a common letter are not significantly different at the $P<0.05$ level by

Duncan's new multiple range test.

** = Highly significant at $P<0.01$ and ns = non significant 
Y.R. Pandey et al./Response of Pole Type ......

Table 5. Effect of sowing dates on fresh pod yield (t/ha) of different pole bean genotypes at Malepatan, Kaski, $2010-2011$

\begin{tabular}{|c|c|c|c|c|c|}
\hline Genotypes & 16 August & $\begin{array}{l}\text { Date of sowing } \\
31 \text { August }\end{array}$ & 15 September & $\begin{array}{l}\text { Means of } \\
\text { genotypes }\end{array}$ & $\begin{array}{l}\text { F value of } \\
\text { genotypes }\end{array}$ \\
\hline $\begin{array}{l}\text { Trishuli } \\
\text { Four season } \\
\text { Makwanpur } \\
\text { Means of sowing dates } \\
\text { F - value of so wing date } \\
\text { LSD } \\
\text { LSD o os (int.) } \\
\text { CV }(\%)\end{array}$ & $\begin{array}{l}26.48 \\
35.35 \\
31.57 \\
31.13^{x}\end{array}$ & $\begin{array}{c}20.19 \\
24.48 \\
20.54 \\
21.74^{\circ}\end{array}$ & $\begin{array}{c}13.24 \\
15.42 \\
17.22 \\
15.29^{6}\end{array}$ & $\begin{array}{c}1997^{\mathrm{u}} \\
25.08^{*} \\
23.11^{4} \\
22.72 \\
119.10^{* * *} \\
2.19 \\
\text { ns } \\
9.6\end{array}$ & $12.49 * *$ \\
\hline
\end{tabular}

1 Mean values in the same column followed by a common letter are not significantly different at the $P<0.05$ level by

Duncan's new multiple range test.

** = Highly significant at $P<0.01$ and ns = non significant

\section{Pod yield}

The fresh pod yield among the genotypes differed significantly and it was highly affected by the date of sowing. The interaction between genotypes and the sowing dates was non significant (Table 5). The combined analysis over the years showed that the highest fresh pod yield was produced by Four season with an average of $25.08 \mathrm{t} / \mathrm{ha}$ followed by Makwanpur with an average of $23.11 \mathrm{t} / \mathrm{ha}$. The lowest fresh pod yield was produced by Trishuli with an average of $19.97 \mathrm{t} / \mathrm{ha}$. Similar results were also reported by other researchers. Neupane et al. (2008) reported that the pod and dry seed yield in beans was influenced by the genotype. They found that all the genotypes planted on the same date produced varying pod number/plant and seed yield $\left(\mathrm{g} / \mathrm{m}^{2}\right)$ ranging from 5 to 32 and 5.9 to 306.5 respectively. Smittle (1986) reported that the genotypes of lima bean showed considerable variation in pod yield. The date of sowing had greater effect on the yield of fresh pod. The highest fresh pod yield was produced when the crop was sown on 16 August with an average of $31.13 \mathrm{t} /$ ha followed by sown on 31 August (21.74 t/ha) and the lowest (15.29 t/ha) by the crop sown on 15 September. It is obvious from the above results that, delayed sowing results severe decline in pod yield. The lower pod yield in delayed sown crop was mainly due to poor growth of the plants and production of smaller pods. Lower temperature at later stage could be the reason for poor plant growth, production of smaller pods and less number of pods pickings (harvestings). From this study it can be concluded that Four season is the best genotype and mid august is the appropriate sowing time of French bean in the mid hills of western Nepal.

\section{Acknowledgements}

The authors are thankful to the staff of Agriculture Research Station, Malepatan, Kaski for their help in implementing the experiment. We would like to thank Mr. Ram Bahadur KC, Chief of the station for providing the experimental field and technical support. We also wish to record our appreciation to Mr. Sharad Chandra Ghimire for trial conduction and data collection.

\section{References}

Adams, M.W., D.P. Covne, J.H.C. Davis, P.H. Graham and C.A. Francis. 1985. Common bean (Phaseolus vulgaris L.). In: Grain legume crops (Eds. R.J. Summerfield \& E.H. Roberts). Collins, London. pp. 433-476.

Alghamdi, S.S. 2007. Genetic behavior of some selected faba bean genotypes. Afr. Crop Sci. Soc. 8:709-714.

Ali, M. 1989. Response of French bean genotypes to planting dates during winter season Indian J. Pulses Res. 2(1):5963.

Al-Soqeer, A. 2010. Establishment and early growth of some jojoba clones in Al-Qassim Region. Journal of Agronomy 9(4):157-162.

Begum, A., A. Ahad, M.O. Kaisar, M.M. Islam and M.K. Anam. 2003. Effects of sowing dates and fertilizer treatments on the reproductive variability of French bean (Phaseolus vulgaris). Pakistan Journal of Biological Sciences 6(22):1897-1901.

IBPGR. 1982. Descriptor list for Phaseolus vulgaris L. International Board for Plant Genetic Resources, Rome, $32 \mathrm{pp}$.

ICAR. 2003. Handbook of horticulture. Indian council of Agriculture Research, Krishi Anusandhan Bhavan, Pusa, New Delhi 110012. pp. 399-402.

Islam, M.S., M.M. Rahman and T. Hossain. 2010. Physicomorphological variation in hyacinth bean (Lablab purpureus L.). Bangladesh J. Agri. Res. 35(3):431-438. 
Nepal Journal of Science and Technology Vol. 13, No. 2 (2012) 15-20

Neupane, R.K., R. Shrestha, M.L. Vaidya, E.M. Bhattarai and R. Darai. 2008. Agro-morphological diversity in common bean (Phaseolus vulgaris L.) landraces of Jumla, Nepal. In: Proceedings of the fourth international food legumes research conference (Ed. M.C. Kharkwal). New Delhi, India, pp. 639-648.

Pandey, Y.R., D.M. Gautam, M.D. Sharma, R.B. Thapa and K.P. Paudyal. 2011. Variability of French bean in the western mid hills of Nepal. Kasetsart J. (Nat. Sci.) 45:780-792.

Pengelly, B.C. and B.L. Maass. 2001. Lablab purpureus (L.) Sweet-diversity, potential use and determination of a core collection of this multi-purpose tropical legume. Gens. Res. Crop Evol. 48:261-272.

Singh, S.P. 1999. Improvement of small-seeded race Mesoamerican cultivars. In: Common bean improvement in the twenty-first century (Ed. S.P. Singh). Kluwer. Dordrecht, pp. 225-274.

Smittle, D.A. 1986. Influence of cultivar and temperature on lima bean yield and quality. J.Amer. Hort. Sci. 111:655-659.

Swaider, J.M., G.W. Ware and J.P. McCollum. 1992. Producing vegetable crops. 4th ed. Interstate Publishers, USA. 626 pp.

Wallace, D.H., P.A. Gniffke, P.N. Masaya and R.W. Zobel. 1991. Photoperiod, temperature and genotype interaction effects on days and nodes required for flowering of bean. J. Amer. Hort. Sci. 116:34-543.

White, J.W. and D.R. Laing. 1989. Photoperiod response of flowering in diverse genotypes of common bean (Phaseolus vulgaris). Field Crops Res. 22(2):113128. 